(2) Open Access Full Text Article

REVIEW

\title{
Impact of Medication Regimen Simplification on Medication Adherence and Clinical Outcomes in Patients with Long-Term Medical Conditions
}

This article was published in the following Dove Press journal: Patient Preference and Adherence

\author{
Mohamed Hassan Elnaem (D) ${ }^{1,2}$ \\ Nor Afifah Irwan (D) \\ Usman Abubakar (D) ${ }^{1}$ \\ Syed Azhar Syed Sulaiman $\mathbb{D}^{3}$ \\ Mahmoud E Elrggal ${ }^{4}$ \\ Ejaz Cheema $\left.{ }^{5}\right)^{5}$
}

'Department of Pharmacy Practice, Faculty of Pharmacy, International Islamic University Malaysia, Kuantan, Pahang, Malaysia; ${ }^{2}$ Quality Use of Medicines Research Group, Faculty of Pharmacy, International Islamic University Malaysia, Kuantan, Pahang, Malaysia; ${ }^{3}$ Department of Clinical Pharmacy, School of

Pharmaceutical Sciences, Universiti Sains Malaysia, Penang, Malaysia; ${ }^{4}$ Department of Clinical Pharmacy, College of Pharmacy, Umm Al-Qura University, Makkah, Kingdom of Saudi Arabia; ${ }^{5}$ School of Pharmacy, University of Birmingham, Edgbaston, Birmingham BI5 2TT, UK
Correspondence: Ejaz Cheema

School of Pharmacy, University of

Birmingham, Edgbaston, Birmingham BI5

2TT, UK

Tel +44-|2|-4| 46845

Email E.Cheema@bham.ac.uk
Background: This study aims to identify interventions used to reduce medication regimen complexity and to assess their impact on medication adherence and clinical outcomes.

Methods: A literature search was conducted using pre-defined search terms in three scientific databases, including ScienceDirect, ProQuest and MEDLINE. Original research articles published in English between 2009 and 2020 that assessed the impact of medication regimen simplification on medication adherence in patients with long-term medical conditions were eligible for inclusion. Review articles, meta-analysis studies and conference proceedings were excluded. Data charting was done in an iterative process using a studyspecific extraction form.

Results: Of the 684 studies identified through initial searches, 17 studies were included in the review. Nine studies involved simplification of medication regimen related to HIV, while three studies focused on patients with diabetes with or without coronary artery disease. The remaining five studies included medications used among elderly patients or medications related to hypertension, psychiatric disorders, glaucoma and kidney diseases. Three medication regimen simplification strategies were identified; fixed-dose combination $(n=7)$, oncedaily dosing $(n=4)$ and the combination of both fixed-dose and once-daily dosing $(n=6)$. Overall, most of the regimen simplification strategies (14 out of 17) were found to be useful in improving medication adherence. There was no assessment of clinical outcomes in four out of 17 studies. Furthermore, more than half of the studies that assessed clinical outcomes did not show any additional impact on clinical outcomes.

Conclusion: The findings suggest that there was an equal utilization of the three main approaches of regimen simplifications; fixed-dose combination, once-daily dosing and a combination of both. Overall, most of the regimen simplification strategies were found to be effective in improving medication adherence. However, the associated improvement in medication adherence did not extend to improvement in the clinical outcomes.

Keywords: medication adherence, regimen simplification, clinical outcomes, review

\section{Introduction}

Non-adherence to prescribed medications has generally been accepted as a barrier to the effectiveness of prescription treatment in the management of long-term medical conditions. ${ }^{1}$ Non-adherence to prescribed medications is prevalent among patients on long-term therapeutic plan and is associated with an increased risk of hospitalization and mortality risks. ${ }^{2}$ Medication regimen complexity has been identified as one of the significant contributors to the prevalence of non-adherence. ${ }^{3}$ The number and 
frequency of daily prescribed medications are among the typical elements of assessing the complexity of a prescribed regimen. ${ }^{4}$ Regimen complexity is commonly seen among patients with long-term therapeutic needs for conditions such as HIV, diabetes, hypertension, and asthma. ${ }^{5-8}$

Additionally, complex regimens are common in the ageing population due to the prevalence of multiple comorbidities that consequently increase the need for polypharmacy. ${ }^{9}$ Furthermore, frequent hospitalizations lead to changes in the drug therapy regimen, particularly post-hospital discharge, which at times becomes more complex due to the initiation of newly prescribed medicines. ${ }^{10}$ Furthermore, an Italian study that assessed the association of regimen complexity with the risk of medication non-adherence suggested that regimen complexity had an independent association with the relative non-adherence risk. ${ }^{11}$ Consequently, it has been reported that the interventions to reduce regimen complexity are sought to have a potential impact on the level of medication adherence. ${ }^{12}$

Medication regimen simplification is one of the viable strategies that can be employed to reduce the regimen complexity by minimizing the number of prescribed medications through interventions such as the fixed-dose combination (FDC) ${ }^{13}$ Another approach to regimen simplification focuses on reducing the frequency of the prescribed medications to a once-daily regimen where feasible. ${ }^{14}$ However, little has been known about the characteristics and effectiveness of the regimen simplifications implemented in clinical practice. This review, therefore, aims to assess the impact of medication regimen simplification strategies on medication adherence as well as to investigate their associated impact on clinical outcomes in patients with long-term medical conditions. Furthermore, it aims to characterize the types of studies based on the study population and prescribed medications that have been considered as part of regimen simplification interventions.

\section{Methods}

\section{Search Strategy and Identification of the Studies}

Three scholarly databases, ScienceDirect, ProQuest, and MEDLINE, were searched to identify potentially relevant studies. The search terms used were "Medication simplification AND adherence OR compliance" or "Regimen simplification AND adherence OR compliance". Besides, terms related to interventions to reduce medication regimen complexity were also reviewed for the possibility to be included only if the main intervention was regimen simplification. Original research articles that have been published between 2009 and 2020 and reported the implementation of regimen simplification strategies on adult patients with medication regimen complexity were included. The searches were limited to the last ten years to provide a review of the most recently published evidence. Only the studies that were measuring patients' adherence following medication regimen simplification were considered. Meanwhile, studies that were only measuring patients` satisfaction or acceptance based on regimen simplification were excluded. Furthermore, review articles, meta-analysis, book chapters and conference proceedings were excluded. The flowchart of the selection of the studies is presented in Figure 1.

\section{Study Selection and Data Extraction}

Two independent reviewers reviewed the studies based on titles and abstracts following the removal of duplicates. The eligible studies were identified and retrieved at fulltext to consider them for inclusion. A series of meetings, in the beginning, at the middle and end of the data extraction process was conducted to ensure consistency. Any differences were resolved by the inclusion of a third reviewer. Data were extracted from the selected studies in two stages. The first stage collected information regarding the main study elements, which are the author's name, country, year, study design, study population, and study objectives. The second stage extracted information on the implemented simplification strategy and outcome measures for adherence and clinical outcomes. For each of the selected studies, the rationale for simplifying the medication regimen was identified. Furthermore, the impact of regimen simplification on the outcome measures was extracted. A descriptive analysis of the extracted data was performed. Reporting of the key findings was carried out in a consistent pattern with the investigated regimen simplification strategies and outcome measures. Further summarization of the adopted approach for simplification, methods of measuring medication adherence and clinical outcomes and the overall impact of the implemented regimen simplifications were provided.

\section{Results}

Of the 684 studies identified through the searches, a total of 17 studies were selected and included in this review. Nine 


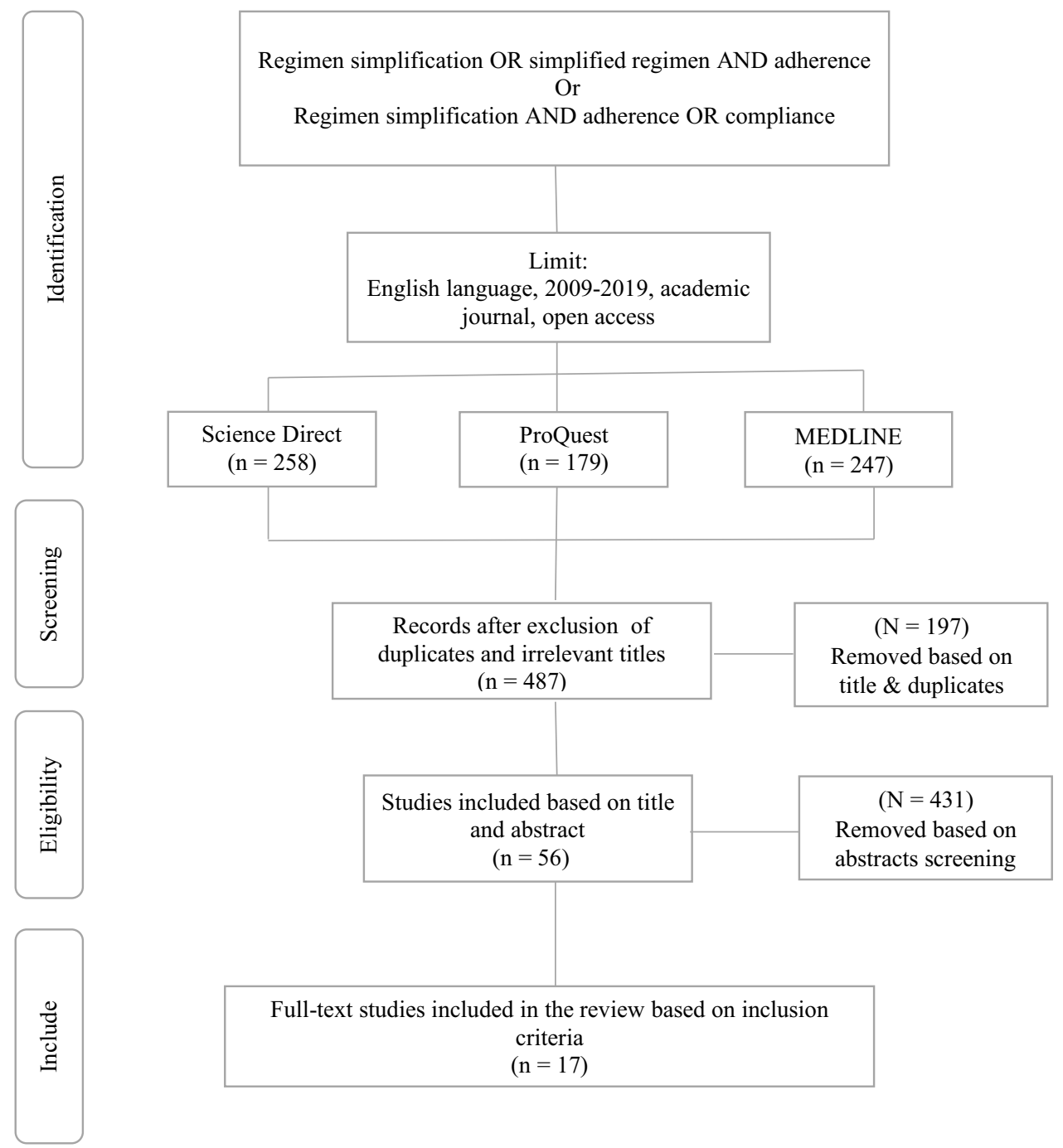

Figure I The process of identification, screening, and inclusion of papers for this review.

studies $(53 \%)$ investigated the simplification of medication regimen in HIV patients, ${ }^{6,15-22}$ and three studies (18\%) involved medication simplification among patients with type 2 diabetes mellitus with or without coronary artery disease (CAD). ${ }^{7,23,24}$ The remaining five studies (29\%) included patients with different conditions such as venous thromboembolism (VTE), psychiatric disorder, glaucoma, kidney transplant and residents of aged care facilities. ${ }^{10,13,14,25,26}$ Almost all the studies reported direct measures of adherence except three studies that reported the potential improvement of adherence as a result of decreasing treatment burden, ${ }^{23}$ increase medication exposure, ${ }^{24}$ and reduce the time of medication administration. ${ }^{26}$ Thirteen of the seventeen studies reported clinical outcomes associated with the simplification of drug regimen, while four studies reported adherence measures with no clinical outcomes. Table 1 shows the characteristics of the studies that focused on the simplification of antiretroviral therapy (ART) regimens.

\section{Simplification of Drug Regimens in Chronic Medical Conditions}

Nine studies were identified that reported on simplification of ART drug regimens. Of these, four were conducted in the US, ${ }^{6,16,17,21}$ two in Spain, ${ }^{15,19}$ and one each in Italy, Brazil and Malaysia. ${ }^{18,20,22}$ Three of the studies were randomized trials, ${ }^{17,20,21}$ four retrospective studies $6,18,19,22$ while two were prospective cohort analyses. $^{15,16}$ In six studies, medication regimen simplification improved medication adherence. ${ }^{6,15,18,20-22}$ One study did not assess the clinical outcomes associated with regimen simplification. ${ }^{19}$ On the other hand, eight studies were identified that reported on the simplification 
Table I Studies That Reported Simplification of Drug Regimens ( $N=\mid 7)$

\begin{tabular}{|c|c|c|c|}
\hline $\begin{array}{l}\text { Author } \\
\text { and } \\
\text { Country }\end{array}$ & Study Design & Study Population & Objectives/Rationale \\
\hline $\begin{array}{l}\text { Angela et al } \\
2010^{6} \text { USA }\end{array}$ & $\begin{array}{l}\text { Retrospective cohort } \\
\text { study involved }\end{array}$ & 75 patients on $A R V$ regimens. & $\begin{array}{l}\text { Examine the impact of pharmacist's intervention on } \\
\text { adherence and clinical outcomes of ARV regimens. }\end{array}$ \\
\hline $\begin{array}{l}\text { Rubio et al } \\
2010^{15} \\
\text { Spain }\end{array}$ & Prospective cohort study & $\begin{array}{l}\text { I } 83 \text { HIV-infected patients on protease } \\
\text { inhibitors (PIs) therapy. }\end{array}$ & $\begin{array}{l}\text { Determine the effectiveness and adherence and of } \\
\text { simplified once-daily dosing of atazanavir boosted with } \\
\text { ritonavir (ATV/r). }\end{array}$ \\
\hline $\begin{array}{l}\text { Buscher } \\
\text { et al } 2012^{16} \\
\text { USA }\end{array}$ & Prospective cohort study & 99 newly diagnosed HIV patients. & $\begin{array}{l}\text { To determine the effect of ART dosing frequency and } \\
\text { number of pills on the adherence of newly diagnosed } \\
\text { HIV patients. }\end{array}$ \\
\hline $\begin{array}{l}\text { Pallela et al } \\
2014^{17} \text { USA }\end{array}$ & $\begin{array}{l}\text { Randomized open-label } \\
\text { trial }\end{array}$ & 476 HIV-I RNA suppressed patients & $\begin{array}{l}\text { To examine the efficacy of antiretroviral simplification } \\
\text { from a ritonavir-boosted protease inhibitor therapy } \\
\text { (NRTI) to STR. }\end{array}$ \\
\hline $\begin{array}{l}\text { Fabbiani } \\
\text { et al } 2014^{18} \\
\text { Italy }\end{array}$ & $\begin{array}{l}\text { Retrospective cohort } \\
\text { study }\end{array}$ & 553 patients on EFV containing regimens. & $\begin{array}{l}\text { Determine the risk of therapy interruption of STR } \\
\text { compared to BID or OD EFV therapy. }\end{array}$ \\
\hline $\begin{array}{l}\text { Arroyo et al } \\
2016^{19} \\
\text { Spain }\end{array}$ & Retrospective study & 264 patients on ART treatment & $\begin{array}{l}\text { Evaluate the influence of the number of daily pills and } \\
\text { daily doses on treatment adherence in a 7-year } \\
\text { pharmaceutical care program. }\end{array}$ \\
\hline $\begin{array}{l}\text { Velvanathan } \\
\text { et al } 2016^{20} \\
\text { Malaysia }\end{array}$ & Randomized control trial. & I20 of HIV patients & $\begin{array}{l}\text { Compare the clinical outcomes, adherence of patients } \\
\text { on FDC vs FRC containing emtricitabine (FTC), } \\
\text { tenofovir (TDF), and efavirenz (EFV). }\end{array}$ \\
\hline $\begin{array}{l}\text { Chen et al } \\
2017^{21} \text { USA }\end{array}$ & Randomized control trial & Involved 750 HIV patients. & $\begin{array}{l}\text { To assess adherence barriers in correlation with STR, } \\
\text { single-dose MTR, and multi-dose MTR of ART. }\end{array}$ \\
\hline $\begin{array}{l}\text { Laliberte' } \\
\text { et al } 2013^{14} \\
\text { USA }\end{array}$ & $\begin{array}{l}\text { Retrospective cohort } \\
\text { study }\end{array}$ & $\begin{array}{l}5756 \text { patients with venous } \\
\text { thromboembolism (VTE). }\end{array}$ & $\begin{array}{l}\text { Evaluate the adherence rates between OD and BID } \\
\text { chronic medication regimens for DM and HTN in } \\
\text { patients with VTE. }\end{array}$ \\
\hline $\begin{array}{l}\text { Stange et al } \\
2013^{7} \\
\text { Germany }\end{array}$ & $\begin{array}{l}\text { Prospective, semi- } \\
\text { randomized trial }\end{array}$ & $\begin{array}{l}240 \text { adult inpatients with HTN, DM, and/or } \\
\text { dyslipidemia. }\end{array}$ & $\begin{array}{l}\text { To examine the impact of structured pharmacist's } \\
\text { intervention on healthcare providers on reducing the } \\
\text { complexity of the medication regimen. }\end{array}$ \\
\hline $\begin{array}{l}\text { Pauly et al } \\
2015^{10} \\
\text { Germany }\end{array}$ & $\begin{array}{l}\text { Prospective open clinical } \\
\text { trial }\end{array}$ & 269 psychiatric patients. & $\begin{array}{l}\text { Assess the effect of multi-dimensional interventions in } \\
\text { improving adherence to complex regimen therapy. }\end{array}$ \\
\hline $\begin{array}{l}\text { Barnebey \& } \\
\text { Robin } \\
2017^{13} \text { USA }\end{array}$ & $\begin{array}{l}\text { Randomised controlled } \\
\text { trial }\end{array}$ & $\begin{array}{l}8 \mathrm{I} \text { adult patients diagnosed with open-angle } \\
\text { glaucoma or ocular hypertension. }\end{array}$ & $\begin{array}{l}\text { To assess the adherence of TTFC with unfixed agents } \\
\text { of travoprost and timolol (TRAV+ TIM). }\end{array}$ \\
\hline $\begin{array}{l}\text { Taybani et al } \\
2019^{23} \\
\text { Hungary }\end{array}$ & $\begin{array}{l}\text { Prospective single-arm } \\
\text { clinical trial }\end{array}$ & 62 patients with T2DM. & $\begin{array}{l}\text { Assess the impact of switching insulin therapy from } \\
\text { MDI to the once-daily fixed-ratio combination. }\end{array}$ \\
\hline $\begin{array}{l}\text { Oh C.K et al } \\
2020^{25} \\
\text { South Korea }\end{array}$ & Prospective cohort trial & 160 kidney transplant recipients. & $\begin{array}{l}\text { Evaluate the medication adherence of tacrolimus, } \\
\text { sirolimus, and corticosteroids as a simplified once-daily } \\
\text { immunosuppressive regimen. }\end{array}$ \\
\hline
\end{tabular}

(Continued) 
Table I (Continued).

\begin{tabular}{|l|l|l|l|}
\hline $\begin{array}{l}\text { Author } \\
\text { and } \\
\text { Country }\end{array}$ & Study Design & Study Population & Objectives/Rationale \\
\hline $\begin{array}{l}\text { Dudl et al } \\
2009^{24} \text { USA }\end{array}$ & $\begin{array}{l}\text { Three-year observational } \\
\text { study }\end{array}$ & $\begin{array}{l}170,024 \text { patients with diabetes, CAD, or } \\
\text { both. }\end{array}$ & $\begin{array}{l}\text { To assess the effect of promoting a bundle of fixed } \\
\text { doses of a generic statin and angiotensin-converting } \\
\text { enzyme inhibitor/angiotensin receptor blocker (ACEI/ } \\
\text { ARB), }\end{array}$ \\
\hline $\begin{array}{l}\text { Sluggett } \\
\text { et al } 2020^{26} \\
\text { Australia }\end{array}$ & $\begin{array}{l}\text { Pre-planned secondary } \\
\text { analysis of a cluster } \\
\text { randomized controlled } \\
\text { trial }\end{array}$ & $\begin{array}{l}242 \text { residents of eight residential aged care } \\
\text { facilities (simplification was done for } 62 \\
\text { residents in interventional arm) }\end{array}$ & $\begin{array}{l}\text { To evaluate the impact of a medication regimen } \\
\text { simplification on medication administration times, falls, } \\
\text { hospitalization and mortality at I2 months follow up. }\end{array}$ \\
\hline $\begin{array}{l}\text { S.F Dos } \\
\text { Santos } \\
\text { et al }{ }^{22} 2020 \\
\text { Brazil }\end{array}$ & $\begin{array}{l}\text { Retrospective cohort } \\
\text { study }\end{array}$ & $\begin{array}{l}\text { I206 patients using MTR of efavirenz, } \\
\text { tenofovir and lamivudine who switched to } \\
\text { the STR. }\end{array}$ & $\begin{array}{l}\text { To evaluate the impact of switching from MTR to STR } \\
\text { on adherence to cART. }\end{array}$ \\
\hline
\end{tabular}

of drug regimens related to other medical conditions. These included three that were conducted in the US, ${ }^{13,14,24}$ two in Germany, ${ }^{7,10}$ and one each in Hungary, Australia and South Korea. ${ }^{23,25,26}$ There were four prospective clinical trials, ${ }^{7,10,23,25}$ two randomized trials, ${ }^{13,26}$ and two retrospective cohort studies. ${ }^{14,24}$ Three of the studies (3/8) in this category did not assess the clinical outcomes associated with regimen simplifications.

\section{Impact of Simplification Strategies on Outcome Measures}

With regards to ART regimens, a single-tablet regimen and fixed-dose combination were reported in five studies. ${ }^{17,18,20-22}$ Two studies simplified the medication regimen using once-daily dosing. ${ }^{15,16}$ Another two studies considered simplification by reducing both the number and frequency of given medications. ${ }^{6,19}$ Regarding the simplification for regimens other than ART regimens, four studies simplified regimen by adopting a single approach. ${ }^{13,14,24,25}$ Whereas in the other four studies, mixed simplification strategies were implemented. $^{7,10,23,26}$ Table 2 provides an overview of the simplification strategies for regimens of different conditions and their impact on outcome measures.

\section{Discussion}

In a recent meta-analysis, the association between the degree of medication complexity and the clinical outcomes of hospitalisation, hospital readmission and medication non-adherence across different studies has been reported. ${ }^{27}$ Furthermore, $^{2}$ a recent systematic review on the medication adherence interventions highlighted the need to focus on the interventions that deemed to be effective to improve adherence such as medication regimen simplification, education and reminders. ${ }^{28}$ However, to the author's knowledge, this is the first study that has assessed the impact of medicine regimen simplification strategies on medicine adherence and clinical outcomes in patients with long-term medical conditions. This study identified three strategies that were used to reduce the complexity of medication regimens; fixed-dose combination, once-daily dosing and a combination of more than one approach. Overall, most of the regimen simplification strategies were found to be useful in improving medicine adherence. Although it can be expected that improving medicine adherence would positively impact clinical outcomes, the findings of this study suggest that clinical outcomes were not consistently enhanced by regimen simplification in a pattern that is consistent with an improvement in medicine adherence.

\section{Fixed Dosed Combination/Single Tablet Regimen}

The medication regimen factors such as the dosing frequency and the degree of medication regimen complexity have been highlighted as factors affecting medication adherence among patients on chronic therapies. ${ }^{29}$ Moreover, in a recent systematic review that investigated the association between medication regimen complexity and adherence to the prescribed pharmacotherapy, a decrease in medication adherence was observed 
Table 2 Simplification Strategies of Drug Regimens and Its Impact on Outcome Measures (N=17)

\begin{tabular}{|c|c|c|c|c|}
\hline $\begin{array}{l}\text { Author } \\
\text { and } \\
\text { Country }\end{array}$ & $\begin{array}{l}\text { Simplification } \\
\text { Strategy }\end{array}$ & $\begin{array}{l}\text { Outcome } \\
\text { Measures } \\
\text { (Adherence) }\end{array}$ & $\begin{array}{l}\text { Outcome Measures } \\
\text { (Clinical) }\end{array}$ & Impact on Outcomes \\
\hline $\begin{array}{l}\text { Angela et al } \\
2010^{6} \text { USA }\end{array}$ & $\begin{array}{l}\text { Reducing pill burden } \\
\text { and dosing frequency }\end{array}$ & Refill records & CD4 count & $\begin{array}{l}\text { Increase treatment adherence and improve clinical } \\
\text { outcomes. }\end{array}$ \\
\hline $\begin{array}{l}\text { Rubio et al } \\
2010^{15} \\
\text { Spain }\end{array}$ & Once-daily dosing & Self-reported & $\begin{array}{l}\text { Assessment of } \\
\text { virological failure }\end{array}$ & $\begin{array}{l}\text { Retained virological response with a slight improvement } \\
\text { in adherence. }\end{array}$ \\
\hline $\begin{array}{l}\text { Buscher } \\
\text { et al } 2012^{16} \\
\text { USA }\end{array}$ & Once-daily dosing & $\begin{array}{l}\text { Visual analogue } \\
\text { scale. }\end{array}$ & $\begin{array}{l}\text { Assessment of } \\
\text { treatment failure (HIV- } \\
\text { RNA levels) }\end{array}$ & $\begin{array}{l}\text { Greater adherence with no difference in clinical } \\
\text { outcomes. }\end{array}$ \\
\hline $\begin{array}{l}\text { Palella et al } \\
2014^{17} \text { USA }\end{array}$ & Single tablet regimen & $\begin{array}{l}\text { Visual analogue } \\
\text { scale. }\end{array}$ & $\begin{array}{l}\text { Virological } \\
\text { suppression }\end{array}$ & $\begin{array}{l}\text { Maintained virological suppression. No difference in } \\
\text { adherence. }\end{array}$ \\
\hline $\begin{array}{l}\text { Fabbiani } \\
\text { et al } 2014^{18} \\
\text { Italy }\end{array}$ & Single tablet regimen & $\begin{array}{l}\text { Treatment } \\
\text { discontinuation }\end{array}$ & $\begin{array}{l}\text { Virological } \\
\text { suppression }\end{array}$ & Higher adherence and lower virological failure \\
\hline $\begin{array}{l}\text { Arroyo et al } \\
2016^{19} \\
\text { Spain }\end{array}$ & $\begin{array}{l}\text { Reducing daily doses } \\
\text { and pills }\end{array}$ & Dispensing records & No assessment & Higher adherence levels. \\
\hline $\begin{array}{l}\text { Velvanathan } \\
\text { et al } 2016^{20} \\
\text { Malaysia }\end{array}$ & $\begin{array}{l}\text { Fixed-dose } \\
\text { combination }\end{array}$ & Morisky scores & CD4 count & Improved clinical outcomes and patients' adherence. \\
\hline $\begin{array}{l}\text { Chen et al } \\
2017^{21} \text { USA }\end{array}$ & Single tablet regimen & Pill counts & $\begin{array}{l}\text { CD4 count Viral load } \\
\text { ((HIV-RNA levels) }\end{array}$ & Higher medication adherence and lower viral load \\
\hline $\begin{array}{l}\text { Laliberte' } \\
\text { et al } 2013^{14} \\
\text { USA }\end{array}$ & Once-daily dosing & $\begin{array}{l}\text { MPR and PDC > } \\
80 \%\end{array}$ & No assessment & Higher adherence \\
\hline $\begin{array}{l}\text { Stange et al } \\
2013^{7} \\
\text { Germany }\end{array}$ & $\begin{array}{l}\text { Reducing the number } \\
\text { and frequency of } \\
\text { medications }\end{array}$ & $\begin{array}{l}\text { Self-reported } \\
\text { MARS-D }\end{array}$ & No assessment & No significant change in adherence. \\
\hline $\begin{array}{l}\text { Pauly et al } \\
2015^{10} \\
\text { Germany }\end{array}$ & $\begin{array}{l}\text { Decrease dosing } \\
\text { frequency } \\
\text { Discontinue } \\
\text { unnecessary drugs }\end{array}$ & MARS & No assessment & Enhanced adherence \\
\hline $\begin{array}{l}\text { Barnebey } \\
\text { and Robin } \\
2017^{13} \text { USA }\end{array}$ & $\begin{array}{l}\text { Fixed-dose } \\
\text { combination }\end{array}$ & Dosing aid records & IOP reduction & Better adherence. IOP reductions were similar. \\
\hline $\begin{array}{l}\text { Taybani et al } \\
2019^{23} \\
\text { Hungary }\end{array}$ & $\begin{array}{l}\text { Once-daily dosing } \\
\text { Fixed-dose } \\
\text { combination }\end{array}$ & $\begin{array}{l}\text { Indirect (decrease } \\
\text { treatment burden) }\end{array}$ & $\begin{array}{l}\text { HbAlc level } \\
\text { Glycaemic control }\end{array}$ & $\begin{array}{l}\text { Effective decreased treatment burden and may improve } \\
\text { adherence to therapy. }\end{array}$ \\
\hline $\begin{array}{l}\text { Oh C.K et al } \\
2020^{25} \\
\text { South Korea }\end{array}$ & Once-daily dosing & $\begin{array}{l}\text { Self-reported (TBS } \\
\text { scores) }\end{array}$ & $\begin{array}{l}\text { Biopsy confirmed } \\
\text { acute rejection } \\
\text { (BCAR) }\end{array}$ & Improved adherence without risk of treatment failure. \\
\hline
\end{tabular}

(Continued) 
Table 2 (Continued).

\begin{tabular}{|l|l|l|l|l|}
\hline $\begin{array}{l}\text { Author } \\
\text { and } \\
\text { Country }\end{array}$ & $\begin{array}{l}\text { Simplification } \\
\text { Strategy }\end{array}$ & $\begin{array}{l}\text { Outcome } \\
\text { Measures } \\
\text { (Adherence) }\end{array}$ & $\begin{array}{l}\text { Outcome Measures } \\
\text { (Clinical) }\end{array}$ & Impact on Outcomes \\
\hline $\begin{array}{l}\text { Dudl et al } \\
2009^{24} \text { USA }\end{array}$ & $\begin{array}{l}\text { Fixed-dose } \\
\text { combination }\end{array}$ & $\begin{array}{l}\text { Indirect } \\
\text { (medication bundle } \\
\text { exposure) }\end{array}$ & $\begin{array}{l}\text { Risk of hospitalization } \\
\text { for MI or stroke in the } \\
\text { following year. }\end{array}$ & $\begin{array}{l}\text { Higher medication exposure and decreased risk of MI or } \\
\text { stroke hospitalization. }\end{array}$ \\
\hline $\begin{array}{l}\text { Sluggett } \\
\text { et al } 2020^{26} \\
\text { Australia }\end{array}$ & $\begin{array}{l}\text { Long-acting and } \\
\text { combination } \\
\text { formulations }\end{array}$ & $\begin{array}{l}\text { Indirect (reduce } \\
\text { times of } \\
\text { medication } \\
\text { administration) }\end{array}$ & $\begin{array}{l}\text { Risk of falls, } \\
\text { hospitalization, and } \\
\text { mortality. }\end{array}$ & $\begin{array}{l}\text { Significant reduction of medication administration times. } \\
\text { Higher risk of falls. No significant differences were } \\
\text { observed for risk of hospitalization or mortality. }\end{array}$ \\
\hline $\begin{array}{l}\text { Dos Santos } \\
\text { et al } 2020^{22} \\
\text { Brazil }\end{array}$ & Single tablet regimen & $\begin{array}{l}\text { Proportion of days } \\
\text { covered } \\
\text { (PDC } \geq 95 \%)\end{array}$ & Viral load & $\begin{array}{l}\text { Significant increase in adherence levels with no difference } \\
\text { in viral load outcomes }\end{array}$ \\
\hline
\end{tabular}

with the increase in medication regimen complexity. ${ }^{30}$ Therefore, interventions to simplify the prescribed regimens in either dose or frequency were thought to be helpful to show a favourable impact on overall medication adherence among a wide range of patients with chronic conditions such as epilepsy, schizophrenia, dyslipidemia, hypertension, diabetes and HIV. ${ }^{31-36}$ The importance of medication adherence in HIV patients cannot be overemphasized. Non-adherence to ART treatment would lead to resistance and treatment failure. ${ }^{21}$ Therefore, it is crucial to ensure that HIV-infected patients comply with their treatment appropriately. Fixed dosed combination (FDC) combines more than a single agent in one formulation and this generally reduces the number of pills to be consumed, consequently eliminating the need to administer multiple medications.

Our work demonstrated that there was considerable work on medication regimen simplifications for patients with HIV compared to all other chronic conditions. In this review, FDC was used in seven studies and five of them involved ART regimens. In a study conducted in the US that involved HIV patients, the simplification of the regimen had no impact on adherence; however, it showed similar effectiveness compared to the conventional regimen. ${ }^{17}$ One possible reason for the lack of effect on adherence could be the use of a visual analogue scale (VAS) to measure adherence. Finitsis et al highlighted that VAS as a measure for adherence had a small association with clinical outcomes and needs further methodological verification. $^{37}$

On the contrary, an Italian study reported that a simplified ART regimen was associated with less treatment interruption and better effectiveness. ${ }^{18}$ Similarly, in a recent US study, a simplified regimen of ART therapy involving Single-Tablet Regimen (STR) was reported to be associated with higher adherence levels and better clinical outcomes. ${ }^{21}$ In addition, a study conducted in Malaysia also reported that the FDC of the ART regimen was associated with an increase in clinical outcomes and adherence levels. ${ }^{20}$ In the context of ART regimens, convenient methods that reduce the number of daily pills increased medicine adherence and improved clinical outcomes. It is essential to highlight that the primary aim of most of the studies was to provide a more convenient therapeutic option that could at least maintain the same level of viral suppression. However, some studies reported improvement in clinical outcomes, in addition to an increase in adherence levels. $^{18,20,21}$

Apart from ART regimens, a study conducted by Barnebey et al reported a significant increase in adherence after simplifying ophthalmology eye drops for glaucoma using a fixed-dose combination. However, there was no significant difference in clinical outcomes. ${ }^{13}$ Besides, previous studies also discussed the use of FDC glyburide-metformin as a simplification strategy for diabetic patients in one single fixed combination to lessen the pill requirement, reduce treatment complexity and increase patients' adherence. ${ }^{38,39}$ Furthermore, studies that compared the adherence rate of FDC amlodipine-benazepril with the corresponding free-drug combinations in hypertensive patients, showed higher adherence in the former. ${ }^{40,41}$ It is therefore noticeable that the use of a fixed-dose combination is more reported in the context of simplifying the ART regimens with a high probability of improving adherence and at least maintain the same clinical outcomes. Furthermore, it seems to be a reasonable simplification strategy in a range of 
other medical conditions that require regular use of multiple medications such as diabetes, hypertension and glaucoma.

\section{Once-Daily Dosing}

The once-daily (OD) dosing frequency is an approach that reduces regimen complexity with evidence showing a higher adherence rate with OD dosing. ${ }^{14,19,25,42,43}$ In a metanalysis conducted to investigate the impact of dosing frequency on the medication adherence among patients with chronic CVD, the findings showed that approximately the once-daily dosing of the prescribed pharmacotherapy was associated with $50 \%$ decrease in the non-adherence risk although the impact on clinical outcomes was not well established. ${ }^{44}$ The approach of simplifying medication using the OD dosing regimen was identified in four included studies. In a Spanish study, it was observed that simplification to once-daily dosing ART regimen was associated with better clinical outcomes and with slight variation in the self-reported adherence. ${ }^{15}$ In contrast, Buscher et al showed that a simplified once-daily ART regimen had no impact on clinical outcomes despite the improvement in the adherence measured by VAS. ${ }^{16}$ On the other contrary, a US study that investigated the impact of OD simplification on the adherence to hypertensive and anti-diabetic medications reported a positive effect on medicine adherence. ${ }^{14}$ In this study, there was no assessment for clinical outcomes. Furthermore, in a study aimed at simplifying immunosuppressant regimens for kidney transplant patients, it was found that OD simplified regimens were associated with a higher level of self-reported adherence with no risk of treatment failure. ${ }^{25}$

Similarly, a study involving anti-asthmatic medications carried out by Kuna et $\mathrm{al}^{43}$ in 2005 showed a greater impact of adherence on the maintenance therapy of OD budesonide-formoterol due to its convenient administration. The OD dosing may specifically be appropriate for patients with mild asthma who are reported to neglect their maintenance therapy during the symptom-free period. ${ }^{43}$ After all, simplified dosing frequency does influence a patient's compliance with long-term medication therapy.

\section{Combination of More Than One Simplification Strategy}

In six studies, the simplification strategies used a combination of both decreasing the pills burden and dosing frequency. It has been reported that both adherence and clinical outcomes are enhanced following the simplification of the ART regimen. ${ }^{6}$ Similar findings for adherence have also been reported by researchers in Spain. ${ }^{19}$
Concerning oral diabetic and hypertensive medications, a combined simplification strategy was not associated with a noticeable impact on adherence. ${ }^{7}$ However, the combined simplification intervention was associated with improvement in adherence with regards to injectable insulins. ${ }^{23}$ Similar positive impact on adherence to antipsychotic medications was also reported in a German study that used a combined simplification strategy. ${ }^{10}$

Interestingly, a study that showed the effect of OD dosing of ART regimen on adherence, the researcher did compare it to a fixed-dose combination of this OD dosing but failed to show any noticeable difference. ${ }^{16}$ It is important to highlight that the implemented simplification strategy to enhance the adherence among psychiatric patients was part of multidimensional interventions including counselling and comprehensive medication review. Overall, in this category, the adherence levels were most likely to be improved, but the clinical outcomes were not reported or experienced modest improvement.

In a recent Australian study that involved an overall eight aged care facilities, the simplifaction was adopted mainly through the use of long-acting and combination regimens where available. ${ }^{26}$ Unlike other studies that had a medication or regimen in the focus of the simplification, this Australian study was introducing the simplification as a feasible approach to be followed to decrease the medications burden as long as the alternatives were available. We acknowledge that the improvement of medication adherence among elderly individuals is modulated by a broad spectrum of educational, behavioural factors besides the interventions that could be initiated and managed through the healthcare providers, ${ }^{45}$ Among those interventions that could be initiated by healthcare providers, medication regimen simplification was found to be a feasible and effective strategy, however, it requires further training and time allocation for better outcomes. ${ }^{4}$

\section{The Overall Impact of Regimen Simplification on Adherence and Clinical Outcomes}

Across all the seventeen studies included in this review, three studies reported no significant impact on adherence following regimen simplification. ${ }^{7,15,17}$ Noticeably in these three studies, the assessment of adherence was predominantly self-reported. However, future studies should be consistent in the use of quantitative measures for assessing 
medicine adherence to determine the actual impact on adherence following regimen simplification strategies.

Unlike adherence, the impact of regimen simplification on clinical outcomes was not conclusive because of the lack of assessment of the clinical outcomes in four of the included studies. $^{7,10,14,19}$ In addition, more than half of the remaining studies showed that the simplified regimens demonstrated the same clinical outcomes as compared to conventional regimens. It can, therefore, be concluded that there is relatively little evidence to support that regimen simplifications improve clinical outcomes. This finding was consistent with a previously conducted meta-analysis that showed that simplification the prescribed pharmacotherapy was not consistently linked to improvement in clinical outcomes despite its positive impact on medication adherence. ${ }^{44}$

In a recent Jordanian study among patients with osteoporosis, it has been observed that the medication non-adherence was affected by the increased number of prescribed medications. ${ }^{46}$ Therefore, a simplified regimen possibly with STR or fixed-dose combination might provide a reasonable clinical solution to improve adherence. Moreover, a metaanalysis by Igaly et al has indicated that once-weekly dosing of treatment for osteoporosis was associated with better adherence levels and higher odds of being adherent as compared to the once-daily dosing. ${ }^{47}$

It is important to highlight that simplification of medication regimens does not necessarily need to be designed as interventions to address problems of non-adherence. Instead, it can be considered an approach followed by the healthcare providers to initiate, change and individualise the therapeutic choices to be more likely encouraging patient compliance to the anticipated medication-taking behaviours. ${ }^{48}$ Also, previous evidence has highlighted that the interventions considering other educational and behavioural aspects in addition to the interventions initiated by healthcare providers will more likely to have a relatively sustained impact on medication adherence. ${ }^{45}$ There is sufficient evidence to support that the pharmacist being one of the primary healthcare providers responsible for improving medication adherence, ${ }^{49}$ is expected to play a crucial role in initiating and applying feasible interventions for medication regimen simplifications. ${ }^{4,26}$

This study has some limitations. Quality assessment of the included studies was not conducted. The searches were restricted to three databases that may have limited the opportunity to identify further eligible studies published in other relevant databases. Furthermore, since the study was limited to the inclusion of published literature only, publication bias is probable.

\section{Conclusion}

This review identified three main strategies used for regimen simplifications; fixed-dose combination, once-daily dosing, and a combination of both fixed-dose combination and oncedaily dosing. Overall, the strategies were found to be useful and feasible to improve medication adherence. However, clinical outcomes were not consistently improved by regimen simplification interventions in a pattern that is consistent with the increase in adherence. Future work may be directed at refining the use of feasible streamlined drug regimens with a greater emphasis on the impact on clinical outcomes.

\section{Abbreviations}

ARV, antiretroviral; ART, antiretroviral therapy; cART, combination antiretroviral therapy; PIs, protease inhibitors; ATV/r, atazanavir boosted with ritonavir; $\mathrm{OD}$, once daily; BID, twice daily; FDC, fixed-dose combination; FC, fixed combination; STR, single-tablet regimen; EFV, efavirenz; FTC, emtricitabine; TDF, tenofovir; FRC, free-dose combination; MTR, multi-tablet regimen; MDI, multiple daily injections; VTE, venous thromboembolism; HTN, hypertension; DM, diabetes mellitus; TTFC, FC of travoprost/timolol; MARS, Medication Adherence Rating Scale; PDC, proportions of days covered; MPR, medication possession ratio; TBS, therapy barrier scale.

\section{Disclosure}

The authors report no conflicts of interest in this work.

\section{References}

1. Fischer MA, Stedman MR, Lii J, et al. Primary medication non-adherence: analysis of 195,930 electronic prescriptions. J Gen Intern Med. 2010;25(4):284-290. doi:10.1007/s11606-010-1253-9

2. Ho PM, Rumsfeld JS, Masoudi FA, et al. Effect of medication nonadherence on hospitalization and mortality among patients with diabetes mellitus. Arch Intern Med. 2006;166(17):1836-1841. doi:10.1001/archinte.166.17.1836

3. de Vries ST, Keers JC, Visser R, et al. Medication beliefs, treatment complexity, and non-adherence to different drug classes in patients with type 2 diabetes. J Psychosom Res. 2014;76(2):134-138. doi:10.1016/j.jpsychores.2013.11.003

4. Elliott RA. Reducing medication regimen complexity for older patients prior to discharge from hospital: feasibility and barriers. JClin Pharm Ther. 2012;37(6):637-642. doi:10.1111/j.1365-2710.2012.01356.x

5. Kerwin EM, Nathan RA, Meltzer EO, et al. Efficacy and safety of fluticasone propionate/salmeterol $250 / 50 \mathrm{mcg}$ diskus administered once daily. Respir Med. 2008;102(4):495-504. doi:10.1016/j. rmed.2007.12.002

6. Ma A, Chen DM, Chau FM, Saberi P. Improving adherence and clinical outcomes through an HIV pharmacist's interventions. AIDS Care. 2010;22(10):1189-1194. doi:10.1080/09540121003668102

7. Stange D, Kriston L, Von-Wolff A, Baehr M, Dartsch DC. Reducing cardiovascular medication complexity in a German University Hospital: effects of a structured pharmaceutical management intervention on adherence. J Manag Care Pharm. 2013;19(5):396-407. 
8. Benner JS, Chapman RH, Petrilla AA, Tang SSK, Rosenberg N, Schwartz JS. Association between prescription burden and medication adherence in patients initiating antihypertensive and lipid-lowering therapy. Am J Health Pharm. 2009;66 (16):1471-1477. doi:10.2146/ajhp080238

9. Witticke D, Seidling HM, Lohmann K, Send AFJ, Haefeli WE. Opportunities to reduce medication regimen complexity: a retrospective analysis of patients discharged from a University Hospital in Germany. Drug Saf. 2013;36(1):31-41. doi:10.1007/ s40264-012-0007-5

10. Pauly A, Wolf C, Mayr A, Lenz B, Kornhuber J, Friedland K. Effect of a multi-dimensional and inter-sectoral intervention on the adherence of psychiatric patients. PLoS One. 2015;10(10):1-18. doi:10.1371/journal.pone. 0139302

11. Corsonello A, Pedone C, Lattanzio F, et al. Regimen complexity and medication nonadherence in elderly patients. Ther Clin Risk Manag. 2009;5(1):209-216. doi:10.2147/tcrm.s4870

12. Choudhry NK, Fischer MA, Avorn J, et al. The implications of therapeutic complexity on adherence to cardiovascular medications. Arch Intern Med. 2011;171(9):814-822. doi:10.1001/archinternmed.2010.495

13. Barnebey HS, Robin AL. Adherence to fixed-combination versus unfixed travoprost $0.004 \% /$ timolol $0.5 \%$ for glaucoma or ocular hypertension: a randomized trial. $\mathrm{Am} J$ Ophthalmol. 2017;176:61-69. doi:10.1016/j.ajo.2016.12.002

14. Laliberte F, Bookhart BK, Nelson WW, et al. Impact of once-daily versus twice-daily dosing frequency on adherence to chronic medications among patients with venous thromboembolism. Patient. 2013;6 (3):213-224. doi:10.1007/s40271-013-0020-5

15. Rubio R, Serrano O, Carmena J, et al. Effect of simplification from protease inhibitors to boosted atazanavir-based regimens in real-life conditions. HIV Med. 2010;11(9):545-553. doi:10.1111/j.14681293.2010.00827.x

16. Buscher A, Hartman C, Kallen MA, Giordano TP. Impact of antiretroviral dosing frequency and pill burden on adherence among newly diagnosed, antiretroviral-naïve HIV patients. Int $J$ STD AIDS. 2012;23(5):351-355. doi:10.1258/ijsa.2011.011292

17. Palella FJ, Fisher M, Tebas P, et al. Simplification to rilpivirine/ emtricitabine/tenofovir disoproxil fumarate from ritonavir-boosted protease inhibitor antiretroviral therapy in a randomized trial of HIV-1 RNA-suppressed participants. AIDS. 2014;28(3):335-344. doi:10.1097/QAD.0000000000000087

18. Fabbiani M, Zaccarelli M, Grima P, et al. Single tablet regimens are associated with reduced efavirenz withdrawal in antiretroviral therapy naïve or switching for simplification HIV-infected patients. BMC Infect Dis. 2014;14(1):1-8. doi:10.1186/1471-2334-14-26

19. Hernández Arroyo MJ, Cabrera Figueroa SE, Sepúlveda Correa R, Valverde Merino MP, Luna Rodrigo G, Domínguez-Gil Hurlé A. Influence of the number of daily pills and doses on adherence to antiretroviral treatment: a 7-year study. J Clin Pharm Ther. 2016;41 (1):34-39. doi:10.1111/jcpt.12343

20. Velvanathan T, Islahudin F, Sim BLH, Taha NA. Simplification of HAART therapy on ambulatory HIV patients in Malaysia: a randomized controlled trial. Pharm Pract (Granada). 2016;14 (4):1-8. doi:10.18549/PharmPract.2016.04.830

21. Chen Y, Chen K, Kalichman SC. Barriers to HIV medication adherence as a function of regimen simplification. Ann Behav Med. 2017;51(1):67-78. doi:10.1007/s12160-016-9827-3

22. Furtado Dos Santos S, Almeida-Brasil CC, Costa JDO, et al. Does switching from multiple to single-tablet regimen containing the same antiretroviral drugs improve adherence? A group-based trajectory modeling analysis. AIDS Care. 2020:1-9. doi:10.1080/ 09540121.2020 .1736258

23. Taybani Z, Bótyik B, Katkó M, Gyimesi A, Várkonyi T. Simplifying complex insulin regimens while preserving good glycemic control in type 2 diabetes. Diabetes Ther. 2019;10(5):1869-1878. doi:10.1007/ s13300-019-0673-8
24. Dudl RJ, Wang MC, Wong M, Bellows J. Preventing myocardial infarction and stroke with a simplified bundle of cardioprotective medications. Am J Manag Care. 2009;15(10):88-94.

25. Oh CK, Bang JB, Kim SJ, et al. Improvement of medication adherence with simplified once-daily immunosuppressive regimen in stable kidney transplant recipients: a prospective cohort study. Asian J Surg. 2020;43(6):660-667. doi:10.1016/j.asjsur.2019.07.011

26. Sluggett JK, Hopkins RE, Chen EY, et al. Impact of medication regimen simplification on medication administration times and health outcomes in residential aged care: 12 month follow up of the SIMPLER randomized controlled trial. J Clin Med. 2020;9(4):1053. doi: $10.3390 /$ jcm 9041053

27. Alves-Conceição V, Rocha KSS, Silva FVN, et al. Are clinical outcomes associated with medication regimen complexity? A systematic review and meta-analysis. Ann Pharmacother. 2020;54(4):301-313. doi: $10.1177 / 1060028019886846$

28. Anderson LJ, Nuckols TK, Coles C, et al. A systematic overview of systematic reviews evaluating medication adherence interventions. Am J Health Pharm. 2020;77(2):138-147. doi:10.1093/ajhp/zxz284

29. Ingersoll KS, Cohen J. The impact of medication regimen factors on adherence to chronic treatment: a review of literature. J Behav Med. 2008;31(3):213-224. doi:10.1007/s10865-007-9147-y

30. Pantuzza LL, Ceccato MDGB, Silveira MR, Junqueira LMR, Reis AMM. Association between medication regimen complexity and pharmacotherapy adherence: a systematic review. Eur $J$ Clin Pharmacol. 2017;73(11):1475-1489. doi:10.1007/s00228-017-2315-2

31. Pellock JM, Smith MC, Cloyd JC, Uthman B, Wilder BJ. Extendedrelease formulations: simplifying strategies in the management of antiepileptic drug therapy. Epilepsy Behav. 2004;5(3):301-307. doi:10.1016/j.yebeh.2004.01.009

32. Suzuki T, Uchida H, Takeuchi H, et al. Simplifying psychotropic medication regimen into a single night dosage and reducing the dose for patients with chronic schizophrenia. Psychopharmacology (Berl). 2005;181(3):566-575. doi:10.1007/s00213-005-0018-3

33. Roitman JL, Kalra S. Interventions to improve adherence to lipid lowering medication. J Cardiopulm Rehabil Prev. 2007;27(2):115. doi:10.1097/01.hcr.0000265040.54651.64

34. Leichter SB, Thomas S. Combination medications in diabetes care: an opportunity that merits more attention. Clin Diabetes. 2003;21 (4):175-178. doi:10.2337/diaclin.21.4.175

35. Poulter NR, Borghi C, Parati G, et al. Medication adherence in hypertension. J Hypertens. 2020;38(4):579-587. doi:10.1097/ HJH.0000000000002294

36. Hung TC, Chen GJ, Cheng SH, et al. Dual therapy with ritonavir-boosted protease inhibitor (PI) plus lamivudine versus triple therapy with ritonavir-boosted PI plus two nucleos(t)ide reverse-transcriptase inhibitor in HIV-infected patients with viral suppression. J Microbiol Immunol Infect. 2019;52(6):865-871. doi:10.1016/j.jmii.2019.07.002

37. Finitsis D, Pellowski J, Huedo-Medina T, Fox MC, Kalichman SC. Visual analogue scale (VAS) measurement of antiretroviral adherence in people living with HIV (PLWH): a meta-analysis. J Behav Med. 2016;39(6):1043-1055. doi:10.1007/s10865-016-9770-6

38. Pan F, Chernew ME, Fendrick AM. Impact of fixed-dose combination drugs on adherence to prescription medications. J Gen Intern Med. 2008;23(5):611-614. doi:10.1007/s11606-008-0544-x

39. Chien HH, Chang CT, Chu NF, et al. Effect of glyburide-metformin combination tablet in patients with type 2 diabetes. J Chin Med Assoc. 2007;70(11):473-480. doi:10.1016/S1726-4901(08)70044-3

40. Dickson M, Plauschinat CA. Compliance with antihypertensive therapy in the elderly: a comparison of fixed-dose combination amlodipine/benazepril versus component-based free-combination therapy. Am J Cardiovasc Drugs. 2008;8(1):45-50. doi:10.2165/00129784-200808010-00006

41. Gerbino PP, Shoheiber O. Adherence patterns among patients treated with fixed-dose combination versus separate antihypertensive agents. Am J Health Pharm. 2007;64(12):1279-1283. doi:10.2146/ ajhp060434 
42. Roca B, Lapuebla C, Vidal-Tegedor B. HAART with didanosine once versus twice daily: adherence and efficacy. Int J Infect Dis. 2005;9 (4):195-200. doi:10.1016/j.ijid.2004.07.006

43. Kuna P, Creemers JPHM, Vondra V, et al. Once-daily dosing with budesonide/formoterol compared with twice-daily budesonide/formoterol and once-daily budesonide in adults with mild to moderate asthma. Respir Med. 2006;100(12):2151-2159. doi:10.1016/j.rmed.2006.03.016

44. Caldeira D, Vaz-Carneiro A, Costa J. The impact of dosing frequency on medication adherence in chronic cardiovascular disease: systematic review and meta-analysis. Rev Port Cardiol (English Ed. 2014;33 (7-8):431-437. doi:10.1016/j.repce.2014.01.014

45. George J, Elliott RA, Stewart DC. A systematic review of interventions to improve medication taking in elderly patients prescribed multiple medications. Drugs Aging. 2008;25(4):307-324. doi:10.2165/00002512200825040-00004

46. Jarab A, Mukattash T, Hilan H. Medication non-adherence in patients with osteoporosis: implications for clinical pharmacists and osteoporosis care providers. Curr Clin Pharmacol. 2020;15:1-8. doi:10.2174/1574884715666200116104754
47. Iglay K, Cao X, Mavros P, Joshi K, Yu S, Tunceli K. Systematic literature review and meta-analysis of medication adherence with once-weekly versus once-daily therapy. Clin Ther. 2015;37 (8):1813-1821.e1. doi:10.1016/j.clinthera.2015.05.505

48. Harmon G, Lefante J, Krousel-Wood M. Overcoming barriers: the role of providers in improving patient adherence to antihypertensive medications. Curr Opin Cardiol. 2006;21(4):310-315. doi:10.1097/ 01.hco.0000231400.10104.e2

49. Elnaem MH, Fatin R, Alhifany AA, Elrggal ME, Cheema E. Impact of pharmacist-led interventions on medication adherence and clinical outcomes in patients with hypertension and hyperlipidemia: a scoping review of published literature. J Multidiscip Health. 2020;635-645. doi:10.2147/JMDH.S257273
Patient Preference and Adherence

\section{Publish your work in this journal}

Patient Preference and Adherence is an international, peer-reviewed, open access journal that focusing on the growing importance of patient preference and adherence throughout the therapeutic continuum. Patient satisfaction, acceptability, quality of life, compliance, persistence and their role in developing new therapeutic modalities and compounds to optimize clinical outcomes for existing disease

\section{Dovepress}

states are major areas of interest for the journal. This journal has been accepted for indexing on PubMed Central. The manuscript management system is completely online and includes a very quick and fair peer-review system, which is all easy to use. Visit http:// www.dovepress.com/testimonials.php to read real quotes from published authors. 